\title{
Intervention for What? The Question of Paternalism
}

Review essay of Authority, by R. Sennett, New York: A. A. Knopf, 1980 and Doing Good: The limits of benevolence, by W. Gaylin, I. Glasser, S. Marcus, \& D. Rothman, New York: Pantheon Books, 1978.

\section{Leslie J. Miller}

University of Calgary

One of the curious features of paternalism is that, while no one will support it, many are drawn to it as a topic of interest. The two volumes under discussion are in important ways about paternalism. Especially, they remind us that paternalism is a slippery form of authority-slippery in the primordial character of its appeal; slippery in the ways it fails to deliver what it promises. Reading these texts, one is confirmed in the feeling that paternalism is the form of authority we love to hate.

As an issue for social theory, much of paternalism's challenge is tied to the fact that paternalistic leaders secure our compliance not by force but by seduction; as daughters and wives, as employees and citizens, and as the clients of institutions of rehabilitation, we are persuaded, even deceived, into trading autonomy for a life of security and regulation. To the modern sensibility, paternalism seems to be a double insult because we are not robbed of our freedom, but rather fooled into relinquishing it. And in a world in which individual freedom is the greatest conceivable good, we are not persuaded that the intervention into our lives which paternalism represents is legitimate.

Sennett's historical discussion suggests that as a form of authority outside its natural familial sphere, the legitimacy of paternalistic authority is increasingly problematic. Unlike earlier forms of fatherbased dominance, such as patrimonialism, the authority of paternalism is not legitimated materially; the paternalist does not derive legitimacy from his power to hand on either property or office. If the paternalistic figure is compelling, then it is for other less obvious reasons.

Paternalism reopens the question of the good of intervention in the life of another who is not a family member but someone who we may scarcely know or see. Thus it requires us to confront our conception of the kind of world we would like to find beyond the home, in politics and in the street. What sort of authority is legitimate in the public sphere? Must the idea of authority be exhausted by the idea of social control? Paternalism is itself an expression of one image of the desirable public life; the rejection of it is an expression of another. 
These two volumes offer an occasion to consider some of these matters.

Sennett's interest in paternalism is in part an interest in the different forms authority assumes according to its place in the social system. He wishes to know, for example, the extent to which paternalism in the workplace or in political life resembles genuine paternal authority in the family. Specifically, he wants to know why the latter is able to nurture independent, mature adults, authoritative in their own right, while the "offspring" of the former grow into individuals capable of rebellion, of resistance toward the boss-what he calls "attitudes of negation"-but of no more. Unlike the authority of the father, paternalism encourages the kind of development which is always aborted at a stage prior to full maturity.

Sennett's discussion employs a familiar distinction between power and authority. Power is the external or coercive aspect of a relation; it becomes legitimate or authoritative only when it can be seen to be underwritten by a caring or nurturant interest. Authority is thus some union of control and care (or, as it is often put, a union of discipline and love). While the nature of power or control is clear enough -it is apparent and can be possessed by virtue of nature or position - the nature of nurturance or care is more difficult. In order to clarify the sense which he wants "nurturance" to bear, Sennett describes two forms of false or flawed authority, each of which in its way fails to respect certain essential features of the genuine caring interest.

The first, paternalism, is described as an "authority of false love," an exercise of control which is accompanied by a version of care as a possession which can be benevolently given or punishingly withheld: "The care for others is the authority's gift, and he will bestow it only so long as it serves his interests" (p. 84). Paternalism violates Sennett's sense of the nature of care because it reduces the latter to a private possession.

Autonomy, "an authority without love," is an exercise of power whose promise of nurturance is concertedly concealed. It is characteristic of the modern bureaucracy; what reduces the employees in a large organization to dependent status, for example, is the expectation of a personalized or embodied care constantly denied. No-one need care for you, for the organization will make it possible for you to care for yourself; this is the message of autonomy, according to Sennett. Autonomy thus violates the sense of nurturance which Sennett wishes to invoke by reducing it to that for which, being no man's possession, no man need take responsibility.

For Sennett, then, familial authority is a happy union of control and care; forms of public authority trade off this model but fail to reproduce it successfully. Specifically, the sterility of public authority is its lack of genuine caring interest. As it shifts its ground from the family to the workplace or to the political arena, the union comes unstuck, with control moving inexorably to the fore. Everywhere 
"father" comes to be associated with "boss" or with "leader," the union undergoes this degeneration and the element of control becomes inflated "beyond its 'natural' measure" (p. 69).

At this juncture Sennett shows that he is willing to risk being labelled a romantic. He believes that we as citizens will continue to seek the good union of control and care in the public sphere and, more than this, that we have the right to find it there. Only the incorporation of a caring interest into the role of authority will successfully invigorate leadership; only the continuing demand of the worker and the citizen to see their emotional lives enriched in the workplace and in politics will recall figures of authority back to the unfashionable recognition that nurturance or care- "the love which sustains others"-is a basic human need (p. 120). Sennett recognizes that his view runs counter to the modern tide which takes for granted the Weberian claim that authority in the public sphere must take the form of either bureaucracy (autonomy) or of dilletantism. Such a choice, he would claim, is born of fear; we reject the possibility of a caring public relation for a lifeless one because the worthy choice renders us vulnerable to the deceptions of the powerful. But this fact, for Sennett, makes the worthy choice no less valid.

Among the memorable observations to be found in Authority is the following: "One of the most avoided subjects of modern society is the relation between being controlled and being cared for" (p. 185), and it is added that the fear of being gulled by the powerful is the best way to summarize the attitudes with which the book is concerned. Nowhere has the truth of this observation been cause for greater remorse than in the helping professions. Once a mainstay of progressive social reform, the notion that the model of the caring parent provided a desirable basis for a program of social action has been utterly undermined. Doing Good is itself an outcome of this upheaval. A collection of four papers (by a psychiatrist, two professionals in the field of social planning and policy, and a social historian), it arose out of an exploratory effort on the part of the New York Council for the Humanities to stimulate discussion between humanists and makers of social policy. From many quarters a single issue very rapidly emerged; as Rothman states in the introduction:

we recognized that a claim once considered to be of the most virtuous sort, the claim to be acting benevolently, had now become-to understate the point-suspect: if the last refuge of the scoundrel was once patriotism, it now appeared to be the activity of "doing good" for others, acting in the best interest of someone else. (p. $x$ )

The view that "doing good" is no longer a response to the needy but rather a mechanism of their social control is the dilemma of the helping professions. The same disintegration of the union of care and control which Sennett laments in the workplace and in political life is to be seen in these fields. Rothman complains that a remark once made by Lionel Trilling has now taken on a new and sinister 
significance: "Some paradox in our nature leads us, once we have made our fellow man the objects of our enlightened interest, to go on to make them the objects of our pity, then of our wisdom, ultimately of our coercion" (p. 72). Thus, paternalistic relations of authority outside the family, especially but not solely those between the state and dependent populations (the aged, the young, the poor, and the handicapped), appear to these authors to be accorded less and less legitimacy; there is now "a widespread and acute suspicion of the very notion of doing good among widely divergent groups on all points of the political spectrum" (p. 82).

Accordingly, the papers in Doing Good explore and add to the indictment of paternalism. Together, they reaffirm the centrality in the family of an innate or genetic response of caring and loving (Gaylin), document the rupture that occurs when one's face-to-face relations give way to the relations of institutional life (Marcus), trace the rise and fall from grace of the paternalistic model since Victorian times (Rothman), and review the proposed conservative response to the dilemma (Glasser).

Since the dilemmas of care are many, it would be well to be clear about the dilemma that is the subject of this volume. Briefly stated, the caring professions have come to realize that the activity of "doing good" is essentially coercive, not merely technically or incidentally so. Let us examine this claim more closely.

The recognition begins, as Rothman's article traces it, in an earlier era when progressive reformers were able to lay the inadequacy of paternalistic institutions such as reformatories, asylums, and almshouses at the door of incompetent administrators and over-frugal legislators; any tyranny that resulted was thought to lie in the policy's implementation, not in the benevolent impulse itself. There arose subsequent efforts to delimit the realm of care which was thought to be "interested" or coercive from that which was not; thus we find even today repeated Sisyphusian efforts to draw the lineas the authors of Doing Good themselves seem to want to do-between caring for and controlling another, or to demarcate the authority of the caretaker from the rights of the cared-for. The culmination of these efforts is to be found in the "safe" definition of rehabilitation as "the delivery of services" which we see today.

In effect, efforts like these desire to establish a purely technical realm of care which could be seen to be unpolluted by the now suspect interests of the caretaker. It was hoped by this means to do good to others without "infantilizing" them. But the ultimate futility of this enterprise-we might regard it as the attempt to commodify care- has been made painfully apparent to those practitioners and policy-makers who are discovering to their dismay that, when the attempt is made to isolate instances of caring practices which are both responsible and also uninterested or free of regulatory features, the sample is rapidly whittled down to none. At length, the desperate conclusion is drawn: an uninterested benevo- 
lence is an illusion. To care for is, essentially, to regulate, to control, ultimately to coerce. Can we do good to others but on their terms? The answer is no.

Assuming then that the rot is in the heart of the enterprise, policy makers like Glasser conclude that the only safe course is to protect the cared-for from the caring: let us now regulate the regulators. Doing Good makes it plain that the helping professions continue to be undone by the poignant practical consequences of this devastating realization. But standing at a different vantage point, we are able to see that in the crystallizing of the dilemma, the helping professions have stumbled upon an important truth: action is interested, not as a technical afterthought but in its very inception. To act is to give voice to-to recommend-some image of the way things ought to be. It is thus also to influence the other-even, as in the classical conception of paideia, to "turn the whole man round." The invitation (for we can now see action as offering the invitation to influence) we can welcome, or lament and repress; we cannot dissolve it. But must we treat this as a lethal discovery as the helping professions have done?

For these professions, facing up to this truth means indeed that to care for is to intervene, but it is an intervention grounded in, or legitimated by, a strong image of the just community. As Sennett rightly points out, the relation between caring for and controlling another (i.e., the essentially interested character of action) is a fearsome subject in modern society; the rout of the helping professions over just this issue is a vivid illustration of his point.

Somehow the modern world-view succeeds in transforming the act which is animated by an image of communal or public good into an act of sheer regulation. What is clear is that in the transformation the legitimating image of communal good has been lost. How has this come about?

Paternalistic authority has its natural home in a pre-modern milieu, one which made familiar the discussion of communal ends. As a sort of secular analogue to religious discussions about what kind of society was pleasing to God, paternalistic communities asked about the moral, or the disciplined, or the industrious society. Like traditional religion, paternalism represented an intervention into individual lives, an intervention legitimated by an entirely visible and familiar vision of communal ends. As a form of authority, it stood for a clear distinction between part and whole, between the realm of private interests and the realm of communal good, and this fact is not changed by the recognition that the good of the whole often turned out in practice to be the good of the owner, or of the boss, or of the politician.

The rise of utilitarian individualism, the ethos of the liberal society, saw an erosion of a distinctive sense of community, making way for the view which considered the only significant end to be maximizing 
individual interest. Thus an ethos of communal good was replaced by an ethos of individual liberty. The commitment to individual liberty and the subsequent reformulation of community as a mere facilitator of private interests is displayed in political and working life in the image of the leader and boss as bureaucrat and, as we noted earlier, in the move within the helping professions to reduce the concept of rehabilitation to the provision of access and the delivery of services. It has affected the fate of other institutions as well, notably traditional religion. Robert Bellah has observed in this connection:

The biblical understanding of national life was based on the notion of community with charity for all the members, a community supported by public and private virtue. The utilitarian tradition believed in a neutral state in which individuals would be allowed to pursue the maximization of their self-interest and the product would be public and private prosperity. (Bellah, 1977, p. 376)

The success of the latter, Bellah goes on to note, transformed religion itself into a means, a "purely private pietism ... with no effective link to virtue, charity or community."

Like traditional biblical religion, paternalism in political life and in the helping professions is now a fossil from a time before individualism subordinated community by reducing it to a mere means. Because it reminds us of the interested or communally grounded character of action, paternalistic authority resists (but is not immune to) being treated as a mere means. But measured against the standard of individualism in the liberal society, the paternalist appears only as an obstacle standing between the individual and his private interests. Intervention for the communal good becomes only the restriction of individual liberty.

As a facilitator of individual liberties, paternalistic authority is indeed a failure. Now the mental institution, the half-way house, and the rehabilitator are one with the jail and the jailer, and all "infantilize" the individual by appearing to stifle his autonomy. Parted forever from a sense of communal virtues for which it once stood, rehabilitation itself has retraced the path of traditional religion; in the same way that religion became a "private pietism" in the Norman Vincent Peale mode, so rehabilitation has also become no more than a technical resource facility for the furthering of purely private freedoms. And in the same coup de grâce, the liberal society has rendered the final end of rehabilitation (as it has rendered the end of religion and of political leadership) utterly devoid of real content. Unable to form a clear picture of communal ends, we become practically unable to distinguish authority or responsibility from outright tyranny.

No wide-awake observer would deny the travesties committed upon individual liberty in the name of benevolence (or traditional religion, for that matter). The dilemma is real. But as Sennett has inti- 
mated, if we close the door to the possibility of a vigorous or a just community because we are aware of tyrannical ones, we lose sight of the important distinction between living and merely surviving. This spectre is all too real at a moment when rehabilitation threatens to mean nothing more than a ramp into every building. The paternalistic community is an immoral community, but must we abandon the idea of community altogether? For the community which is merely a facilitator of private interests is no community at all.

\section{What kind of community}

With these issues in mind, let us return now to the lament running through these volumes. All of the authors rely on the image of familial authority as a standard to measure the failings of the world outside the family. All are concerned with the process of demystification by which benevolent and humanitarian claims of a powerful segment of the population come to be unmasked as efforts to control. Their programmes, however, are different; Sennett hopes to recover the essential unity of authority in the public realm by restoring care as a valid demand; the helping professions (insofar as Doing Good reflects their thinking) appear to be more cynicalhaving less faith in a rejuvenated public authority of Sennett's sort, they resort to a conservative strategy of least intervention. But this is clearly an unhappy course, one taken as a last resort in the face of harsh reality.

Despite the differences amongst these authors, their vision of what is lost-whether irretrievably or not-is a shared one: to the extent that the public realm loses its familial character, it is thereby essentially impoverished. Each essay turns on the assumption that loss of community is identical to the loss of a caring relation between individuals. It should be clear by now, however, that the restoration of community cannot be a matter of the restoration of warmth or affect. While the absence of warmth in the bureaucratic or liberal society may be lamentable, its restoration would leave the weak conception of community as the facilitator of purely private interests essentially untouched. And the image of the public sphere in these two volumes remains undeniably a liberal and individualistic one; it is the image of an arena in which the public interest is in the service of private consumption. In particular (in its incarnation as the welfare state) it is the arena responsible for the equitable distribution of goods and services.

Around this bureaucratic conception of the public realm-as an appendage, as it were-is the increasingly dim prospect of warmth, a caring interest. Both Sennett and Gaylin, et al. concern themselves with the possibility or the advisability of re-hitching the appendage to the body. The problem with the community as these authors see it is with the appendage and not the body itself.

In contrast to this view, we are claiming that the problem with the public sphere is not loss of warmth or affect, or even the reliability of 
these, but rather the loss of a sense of community or public life other than the pursuit of private interests and individual liberties. What is called for here is not warmth but the re-appearance of the forum or polis.

The forum or polis, as Hannah Arendt more than any other writer has reminded us, is the sphere of rhetoric, of discourse about ideals and principles-those things which we choose, in contrast to the things which are required for our survival. Accordingly, the true public man is the citizen, not the consumer. Matters of production and consumption, in this view, properly belong in the household. Over the centuries, the household function has extended itself beyond the family into the society, a drift which culminates in the welfare state. The latter, an impoverished form of community having as its sole business the regulation of production and consumption, has accordingly no real public or civic function. It is the industrial household.

When we accept the liberal definition of the community as the industrial household as do the authors of these two books, we should know what it is that we have accepted. We have a body which facilitates access to private satisfactions, which allows increasing individual autonomy, even at the risk of neglect. Especially, we have the autonomy to consume whatever pleasures we choose. We have a community which, as Michael Walzer recently observed, resembles Brecht's city of Mahagonny, in which "Don'ts are not permitted here."

We should also know what it is that we have not. We do not have a forum or a polis. The restoration of warmth and caring to the industrial household will not alter the fact that the industrial household, as a means to promote exclusively private ends or services, is a prepolitical community. Warmth and intimacy make a community, but a polis is not any kind of community. Walzer puts this point especially well:

From the ancient Greeks, we have learned that politics is the enterprise of friends. But in any strong sense of that word, I doubt that the citizens of the polis were friends, each one of them to all the others. Friendship, like love, describes a more personal relation, and it is probably a mistake to seek the special delights of that relation in the public arena. Certainly, we can have associates, colleagues, co-workers, fellow members, even comrades, with whom we are not particularly friendly. No, when we talk about community ... it is not because we are eager for warmth. ... Communion is for ritual occasions; what we want on an ordinary basis is space and shelter to put our principles into play. (Walzer, 1980, p. 13)

Thus, the deep problem with life outside the household is not loss of warmth but loss of community in this special sense. Life beyond the household is not rapacious because it lacks fellow-feeling, but because it has itself been raped-made the slave of purely household (private) concerns. 
This is why paternalism continues to claim a certain appeal. It is not properly the appeal of a renewed call for regulation in private life, but rather the appeal of the demand that the liberties we have be made socially meaningful or responsive to principles which are worked out in public life. Paternalistic communities are perhaps travesties, but they are still distant cousins of the polis or forum. In the form of the "problem" of the interested character of benevolent action, the faint image of a polis keeps reasserting itself-a stubborn reminder that even the most carefully regulated, scrutinized, apparently technical, disinterested and bureaucratic exchange, between boss and worker, leader and citizen, caretaker and cared-for, is still and finally an echo of a community in which the question of what matters is not simply the question of what is allowed.

\section{References}

Bellah, R. N. (1977). New religious consciousness. In D. H. Wrong \& H. L. Gracey (Eds.), Readings in introductory sociology. New York: Macmillan, pp. 375-388.

Walzer, M. (1980). Radical principles: Reflections of an unreconstructed Democrat. New York: Basic Books, Inc. 